\title{
PENYULUHAN INOVASI PRODUK DAN PEMASARAN INDUSTRI KECIL PANGAN DI DESA GUNUNG MANIK TANJUNGSARI SUMEDANG
}

\author{
Endah Djuwendah dan Tuti Karyani \\ Staf Pengajar Program Studi Agribisnis Fakultas Pertanian Universitas Padjadjaran \\ E-mail: endah.djuwendah@gmail.com
}

\begin{abstract}
ABSTRAK. Industri kecil pangan merupakan salah satu potensi pengerak perekonomian di perdesaan karena dapat menciptakan nilai tambah dan peluang kesempatan kerja. Menciptakan inovasi pada industri kecil pangan adalah hal yang sangat penting untuk meningkatkan daya saing dan nilai penjualan. Penggunaan sistem informasi pemasaran dapat membantu pelaku industri kecil pangan dalam membuat alternatif pemasaran guna meningkatkan volume penjualan. Kegiatan penyuluhan inovasi produk dan pemasaran on line di Desa Gunung Manik merupakan wujud dari penerapan teknologi yang ada pada UndangUndang Nomor 12 Tahun 2012 tentang Pendidikan Tinggi, sehingga diharapkan dapat meningkatkan pendapatan masyarakat desa. Inovasi yang dilakukan meliputi penambahan varian rasa , bentuk dan pengemasan produk ladu. Selain Pelatihan hal lain yang dibutuhkan oleh warga masyarakat adalah media yang membantu dalam memasarkan produk melalui sistem informasi pemasaran dan media sosial seperti Web penjualan, facebook, instagram dan twitter. Materi penyuluhan yang diberikan pada kegiatan PPM ini adalah motivasi dan mental kewirausahaan, inovasi produk dan pengemasan, pemasaran online, sosialisasi keamanan pangan dan tatacara pengajuan sertifikasi P-IRT. Faktor pendorong keberhasilan program adalah adanya dukungan aparat desa dan partisipasi aktif warga masyarakat desa Gunung Manik.
\end{abstract}

Kata kunci: inovasi; produk; industri kecil; pangan, pemasaran

ABSTRACT. Small food industry is one of the potential drivers of the economy in rural areas because it can create added value and employment opportunities. Creating innovation in the small food industry is very important to increase competitiveness and sales value. The use of marketing information systems can help small food industry players in creating marketing alternatives to increase sales volume. Online product innovation and marketing extension activities in Gunung Manik Village are a form of technology application in Law Number 12 of 2012 on Higher Education, so that it is expected to increase the income of rural communities. Innovations include adding flavors, shapes and packaging of ladu products. Besides training, other things needed by the community are media that help in marketing products through marketing information systems and social media such as Web sales, Facebook, Instagram and Twitter. The counseling materials provided in the PPM activities were entrepreneurial motivation and mentality, product innovation and packaging, online marketing and food safety socialization and procedures for filing P-IRT certification. Factors driving the success of the program were the support of village officials and the active participation of Gunung Manik villagers.

Keywords: innovations; products; small industries; food; marketing

\section{PENDAHULUAN}

Industri kecil dan menengah (IKM) di Indonesia memiliki peranan yang sangat penting dan strategis untuk mewujudkan perekonomian daerah yang kokoh dalam menunjang perekonomian nasional. Perekonomian daerah akan berkembang bila industri kecil dan menengah yang ada di desa/ kelurahan mampu tumbuh dan bertahan hidup.

Permasalahan utama industri kecil dan menengah (IKM) di era ekonomi Asean dan revolusi industri 4.0 adalah pemasaran. Sebagian besar pelaku industri kecil dan menengah (IKM) masih menggunakan pemasaran konvensional yaitu dari mulut ke mulut atau getok tular dan pamflet. Perlu di pahami, tidak semua pelaku industri kecil dan menengah (IKM) memiliki sumber daya manusia yang siap dengan perubahan teknologi informasi. Pada umumnya kebanyakan masyarakat memanfaatkan teknologi informasi hanya untuk menjalin hubungan komunikasi dengan orang lain. Padahal keberadaan teknologi informasi bisa mendukung kegiatan ekonomi khususnya dalam hal pemasaran produk (Endra Yuafanedi A, dkk, 2019).

Desa Gunung Manik merupakan salah satu desa swadaya ang terletak sekitar 3 kilometer dari ibukota Kecamatan Tanjungsari dan $30 \mathrm{~km}$ dari ibukota Kabupaten Sumedang. Luas wilayahnya mencapai 245,68 ha yang terbagi ke dalam bebepa penggunaan yaitu sebagai lahan peranian, pemukiman dan lahan lainnya. Lahan pertaniannya 120,31 Ha yang terbagi atas lahan persawahan 65,16 Ha $(26,52 \%)$ dan non persawahan (ladang, kebun, huma) seluas $55,15 \mathrm{Ha}(55,15 \%)$ sisanya seluas $66,67 \mathrm{Ha}(27,14 \%)$ dipergunakan untuk lahan lainya berupa pemukiman, fasilitas umum, pekarangan dan yang lainnya. Tofogragrafi desa Gunung Manik berupa dataran dengan ketinggian 855 meter dari permukaan laut, memiliki suhu harian berkisar $28^{\circ}$ C- $32{ }^{\circ} \mathrm{C}$ dan memiliki curah hujan berkisar 3.500 $\mathrm{mm} /$ tahun (Pemerintah daerah Sumedang, 2019).

Potensi sumber daya manusia berjumlah 10.594 orang yang terhimpun dalam 2.338 kepala keluarga. Desa Gungunmanik memiliki potensi di 
bidang pertanian dan peternakan sehingga mayoritas penduduk bergerak dalam bidang tersebut. Potensi pertaniannya menghasilkan komoditas padi,jagung, ubi jalar, sayuran (tomat, kacang merah dan cabe). Hasil peternakannya berupa sapi, domba, ikan lele dan unggas (Pemerintah daerah Sumedang, 2019) Seluruh pemasaran hasil tanaman pangan, hortikultura dan peternakan dijual ke bandar selanjutnya oleh bandar di jual ke pasar lokal yaitu pasar Tanjungsari dan pasar Sumedang. Hasil pertanian dan peternakan tersebut berpotensi untuk diolah menjadi berbagai produk olahan pangan guna pertambahan nilai (value added) dan menciptakan lapangan kerja.

Ketersediaan sumber daya alam Desa Gunung Manik yang potensial, seharusnya dapat mendukung Gunung Manik menjadi desa mandiri pangan dan memajukan taraf kehidupan masyarakatnya. Namun sumber daya alam tersebut, belum dimanfaatkan secara maksimal dalam meningkatkan perekonomian masyarakat desa terutama mengurangi tingkat pengangguran warga yang berpendidikan rendah (SD, SLTP, SLTA).

Potensi industri kecil Desa Gunung Manik terdiri atas industri pengolahan makanan, kayu, genting dan batu bata, figura, jaring ikan dan anyaman. Hasil observasi lapangan menunjukkan usaha industri kecil pangan didominasi oleh usaha kecimpring, ranginang, keripik singkong, rempeyek, tahu, tempe dan ladu. Usaha industri kecil pangan tersebut memiliki tingkat penguasaan manajemen usaha yang minim, tenaga kerja umumnya di dominasi oleh ibu rumah tangga, lokasi usaha bersatu dengan rumah, kegiatan usaha belum terdaptar dan tidak memiliki sertifikat P-IRT, serta pengemasan produk yang masih sederhana. Hal tersebut berdampak pada pemasaran, dimana produk industri kecil pangan hanya bisa dipasarkan dalam skala pasar lokal tingkat desa dan kecamatan.

Sejalan dengan hasil penelitian Selfiawaty Fausiah (2016) yang menunjukkan bahwa permasalahan utama yang dihadapi para pengusaha industri kecil olahan pangan meliputi ketersediaan modal terbatas, sehingga usaha olahan bahan pangan belum bisa diproduksi secara besar-besaran dan kesulitan mendapatkan izin legalitas produknya dari instansi teknis (Dinas Kesehatan dan Badan POM). Permasalahan itu pula yang membuat daya saing dan pasar industri olahan pangan masih terbatas.।

Kunci dari kewirausahaan adalah pengambilan risiko, menjalankan usaha sendiri, memanfaatkan peluang, menciptakan usaha baru, serta pendekatan yang inovatif dan mandiri Guna menghadapi tantangan dalam pasar, pengusaha UMKM dituntut jeli melihat peluang pasar, beradaptasi terhadap perubahan preferensi konsumen dan dapat memasarkan produknya. Oleh karena itu pengusaha UMKM harus kreatif dan terus berinovasi. Inovasi merupakan kemampuan menerapkan solusi kreatif dalam menghadapi tantangan dengan sesuatu yang baru(Sutisna dan Djuwendah, 2019).

Sejalan dengan tujuan pemerintah yang tertuang pada Undang-undang nomor 12 tahun 2012 tentang pendidikan perguruan tinggi untuk membentuk atau mengembangkan sekelompok masyarakat yang mandiri secara ekonomi, membantu menciptakan ketentraman, dan kenyamanan dalam kehidupan bermasyarakat, dan meningkatkan keterampilan berpikir, membaca dan menulis atau keterampilan lain yang dibutuhkan (Husaeni UA, 2017), maka kegiatan PPM-KKN kewirausahaan dilaksanakan untuk mengaplikasikan berbagai disiplin ilmu dalam upaya membantu menyelesaikan permasalahan khususnya dalam lingkup pengembangan industri kecil pangan.

Adapun tujuan dari kegiatan ini adalah melakukan inovasi produk dan pembuatan sistem informasi pemasaran bagi industri kecil pangan guna meningkatkan daya saing, promosi dan pemasaran produk pangan lokal masyarakat Desa Gunung manik.

\section{METODE}

Kegiatan PPM-KKN Kewirausahaan ini melibatkan mahasiswa dan dosen sebagai pembimbing lapangan KKN. Tujuan dilaksanakannya PPM ini adalah untuk memberdayakan individu dan masyarakat kelompok sasaran, khususnya di bidang industri kecil pangan agar dapat berkembang sebagai usaha produktif yang berdampak luas bagi kesejahteraan masyarakat desa. Tahapan kegiatan PPM-KKN kewirausahaan di desa Gunung Manik Kecamatan Tanjungsari Kabupaten Sumedang dimulai dengan penggalian data dan analisis situasi, perencanaan dan pelaksanaan program dan evaluasi kegiatan. Beberapa pendekatan yang digunakan untuk efektifitas hasil pelatihan adalah (a) Pengumpulan data dan analisis situasi yang dilaksanakan dalam kurun waktu 2 minggu pertama melalui kegiatan observasi, pendataan dan wawancara kepada pelaku industri kecil pangan yang dilakukan oleh dosen dibantu oleh mahasiswa peserta KKN. Data yang terkumpul selanjutnya dianalisis menggunakan Bisnis model kanvas (BMC), (b) Uji coba pengolahan produk pangan lokal yang potensil menjadi produk unggulan desa yaitu ladu, (c) lokakarya penyuluhan dan sosialisasi hasil uji coba produk. Evaluasi program dilakukan melalui pelaporan dan lokakarya desa. Mitra yang terlibat dalam program ini adalah ibu-ibu PKK, pelaku industri kecil pangan dan aparat desa Gunung 
Manik. Metode yang digunakan adalah penyuluhan, pelatihan dan pendampingan.

\section{HASIL DAN PEMBAHASAN}

Setelah melakukan survei tempat, wawancara, serta melihat proses produksi, diperoleh hasil bahwa industri kecil pangan yang berada di Desa Gunung Manik memiliki kendala yang sama, seperti kualitas produk, manajemen usaha dan pemasaran. Untuk mengatasi kendala tersebut tim PPM-KKN kewirausahaan menyelenggarakan empat kegiatan yaitu penyuluhan motivasi mental kewirausahaan, penyuluhan inovasi produk pangan, penyuluhan keamanan pangan dan tatacara pengajuan perijinan P-IRT dan penyuluhan pemasaran on line (e-commerce).

\section{Penyuluhan motivasi mental kewirausahaan}

Supaya masyarakat desa berani mengembangkan usaha dan idenya, perlu diberikan penyuluhan mengenai motivasi. Menurut cahyani (2015)Motivasikewirausahaanmerupakan dorongan yang kuat dalam diri seorang pengusaha untuk mulai mengaktualissikan potensi dalam berpikir kreaif dan inovatif guna memenuhi kebutuhannya secara mandiri tanpa harus bergantung pada orang lain dan agar lebih merasa bangga serta puas atas hasil yang diperoleh melalui kerja keras. Faktor yang mendorong timbulnya motivasi berwirausaha diantaranya adalah Laba, kebebasan, impian personal dan kemandirian (Basrowi, 2011).

Kewirausahaan (entrepreneurship) muncul apabila seseorang individu berani mengembangkan usaha dan ide-ide barunya. Proses kewirausahaan meliputi semua fungsi, aktivitas dan tindakan yang berhubungan dengan perolehan peluang dan penciptaan organisasi usaha (Suryana, 2001 dalam Sembiring S, 2009). Esensi dari kewirausahaan adalah orang yang mampu membaca dan menciptakan peluang di setiap perubahan Wirausahawan adalah figur, inovator bukan plagiator, figure pemimpin bukan pengekor. Ketajaman naluri dan intuisi selalu berproses sebagai latihan dan pengalaman sehingga selalu terbuka peluang bisnis. Faktor-faktor yang perlu dipertimbangkan dalam Kewirausahaan diantaranya: jenis usaha, tempat dan lokasi, prospek pasar dan persaingan, aspek teknologis, perijinan, inovasi dan kreatifitas tinggi.

Materi disampaikan melalui teknis ceramah, diskusi dan permaian bergambar. Peserta mengikuti kegiatan dengan baik. Dari hasil evaluasi ditemukan berbagai kendala dalam motivasi masyarakat untuk berwirausaha diantaranya merasa tidak memiliki kemampuan berbisnis, tidak ada modal usaha dan takut gagal.

\section{Inovasi Ladu sebagai produk unggulan desa}

Ladu ini awal mulanya berasal dari daerah Garut dan sekarang banyak diproduksi oleh para pengrajin di beberapa daerah seperti Kabupaten Bandung, Sumedang dan Canjur. Keberadaan ladu saat ini memiiki peluang besar dalam pengembangan usaha sebagai kuliner khas yang bersaing dengan makanan sejenis dodol ataupun kue lainnya.

Ladu merupakan produk kuliner tradisional yang bahan dasarya terbuat dari tepung ketan putih atau hitam yang dimasak dengan cara digoreng tanpa minyak(disangrai) dan bahan pelengkapnya antara lain gula putih, gula aren dan kelapa yang sudah diparut dan disangrai juga (wikipedia). Ladu berwarna coklat kehitaman, memiliki tekstrur agak kasar dan jika digigit rasanya kenyal seperti dodol namun lebih khas.

Cara pembuatan ladu sangat sederhana. Setelah bahan-bahan terkumpul, langkah pertama adalah mempersiapkan wadah sejenis wajan di atas tungku api yang suhunya bisa diatur stabil. Masukan parutan kelapa yang sudah di sangrai dan dicampur dengan gula aren merah. Aduk dan adonan dipanaskan selama 1,5 jam hingga menjadi cairan kinca yang harum. Masukan gula dan aduk hingga merata. Kemudian tuangkan tepung ketan yang sudah disangrai, supaya tidak lengket, aduk adonan selama 2 jam hingga akhirnya mengental. Setelah matang, tuang adonan ke atas meja yang sudah dialasi pelastik atau kertas kue. Pilin-pilin adonan hingga membentuk pipa berdiameter 3-6 cm, lalu potong-potong dengan panjang sekitar $15-20 \mathrm{~cm}$ lalu dikemas.

Ladu dipilih sebagai sebagai produk unggulan Desa Gunung Manik karena keterampilan pembuatan ladu dikuasi oleh sebagian besar warga desa, rasanya yang sangat enak menjadikan ladu sebagai makanan yang selalu ada dalam setiap kegiatan kenduri di masyarakat desa Gunung Manik seperti acara syukuran pernikahan, khitanan, dan camilan istimewa di hari raya. Ladu Ketan khas Gunung Manik ini tidak menggunakan bahan pengawet. Sehingga masa kadaluarsanya sangat pendek. Rata-rata Ladu Ketan hanya bisa bertahan empat sampai tujuh hari setelah diproduksi. Sebelumnya ladu ini diproduksi dalam bentuk oval berukuran panjang sekitar $15 \mathrm{Cm}$ dan lebar sekitar 5-7 cm dengan berat sekitar 100 gam yang dikemas menggunakan plastik mika dan dijual dengan harga Rp 5000 per buah. (Gambar 1)

Selanjutnya mahasiswa KKN dalam progam PPM-KKN kewirausahaan ini mencoba melakukan inovasi dengan menambahkan bahan lain sebagaI topping yaitu keju coklat meses dan selai rasa strabery. Bentuk juga divariasikan menjadi bentuk bulatan kecil. Kemasan dicoba diperbaiki dengan menggunakan kemasan plastik untuk masing-masing 
bulatan ladu ukuran kecil dengan diameter sekitar 4-5 $\mathrm{cm}$. Selanjutnya ladu yang sudah dibungkus plastik tersebut dimasukan ke dalam kemasan berbentuk standpoch yang mudah dibuka dan terbuat dari bahan ramah lingkungan berupa kertas berwarna coklat. Kemasan luar tersebut diberi label berisi keterangan informasi komposisi produk dan ukuran kemasan. Pada tahap uji coba produk dijual dengan harga $\mathrm{Rp}$ 20.000 per poch ukuran sekitar 250 gram.

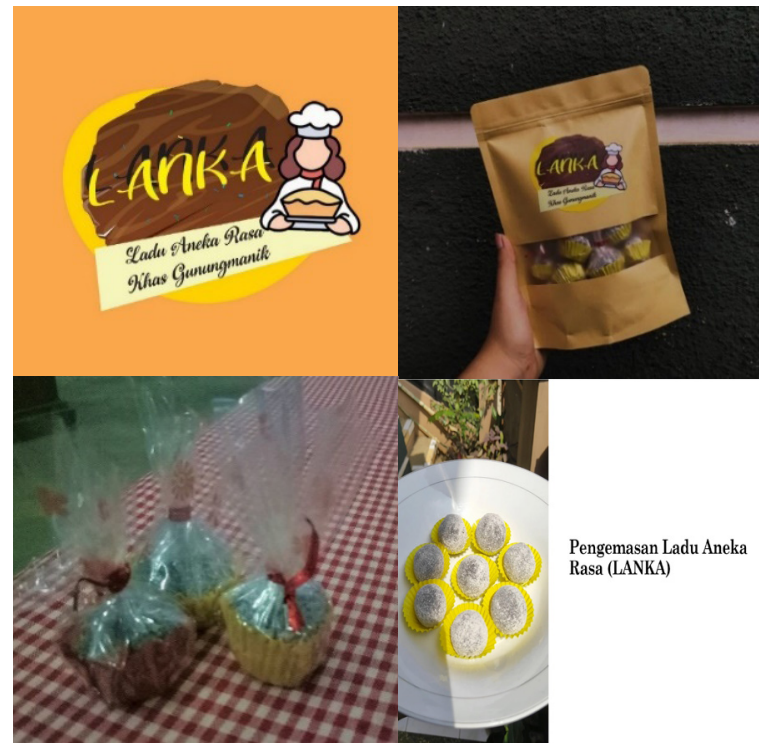

Gambar 1. Hasil Inovasi Produk Ladu Aneka Rasa (LanSa)

\section{Sosialisasi Keamanan Pangan dan pengajuan P-IRT}

Daya saing produk pangan lokal yang dihasilkan IRTP ditentukan oleh pemenuhan persyaratan mutu dan keamanan pangan. Keamanan pangan merupakan salah satu isu yang berkembang di masyarakat, karena masih adanya kasus keracunan pangan, meningkatnya kesadaran, dan tuntutan konsumen terhadap makanan yang aman dan bermutu. Menurut UU No. 18 Tahun 2012, Keamanan pangan diselenggarakan untuk menjaga pangan agar aman, higienis, bermutu dan tidak bertentangan dengan agama, keyakinandan budaya masyarakat. Keamanan pangan juga dimaksudkan untuk mencegah cemaran baik fisik, biologis maupun kimia yang masuk dalam pangan dan dapat membahayakan kesehatan manusia. (Gambar 2).

Menurut Purba, D.F., Nuraida, L., \& Koswara, S. (2014), sertifikasi produksi pangan industri rumah tangga (SPP-IRT) adalah salah satu bentuk kebijakan pemerintah cq. Badan POM RI dalam mengatur, membina dan mengawasi pangan di Indonesia khususnya pangan hasil produksi Industri Rumah Tangga (IRT). Tujuan pengaturan, pembinaan dan pengawasan pangan adalah tersedianya pangan yang memenuhi persyaratan keamanan, mutu dan gizi bagi kepentingan kesehatan manusia, terciptanya perdagangan pangan yang jujur dan bertanggung jawab, dan terwujudnya tingkat kecukupan pangan dengan harga yang wajar dan terjangkau sesuai dengan kebutuhan masyarakat (UU Pangan No. 7 Tahun 1996 Ps.3).

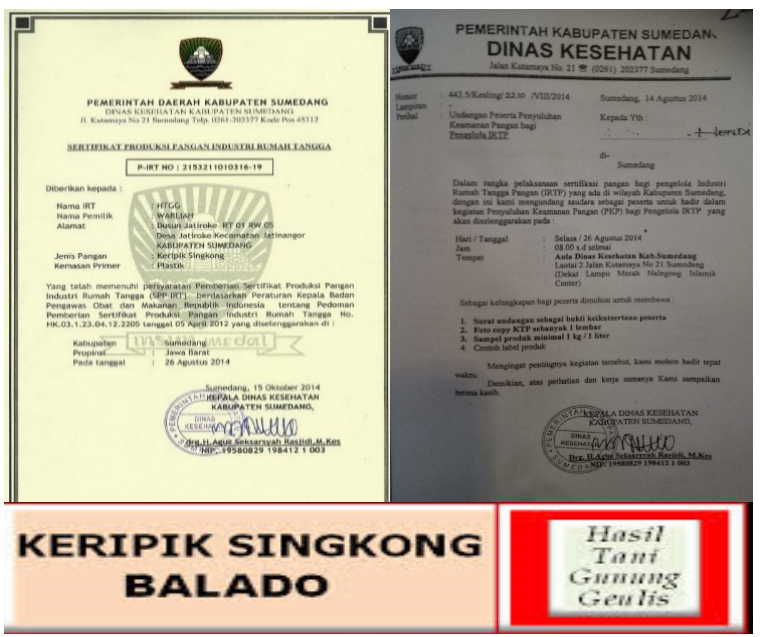

Gambar 2. Pesyaratan dan Contoh Sertifikat P-IRT Hasil Tani Gunung Geulis Jatinangor

Sumber : Hepi Hapsari Endah Dju dan Lies S, 2015

Penyuluhan sosialisasi keamanan pangan dan tatacara pengajuan P-IRT berlangsung di gedung olah raga (GOR) Desa Gunung Manik pada tanggal 12 Februari 2019 yang dihadiri oleh sekitar 30 orang warga yang terdiri dari aparat desa, pelaku industri kecil pangan dan ibu PKK. Setelah penyuluhan dilakukan tanya jawab mengenai zat aditif dalam makanan yang tidak aman bagi kesehatan dan prasyarat untuk pengajuan P-IRT ke Puskesmas dan Deperindag di tingkat Kabupaten.

\section{Sosialisasi Pemasaran On line}

Salah satu kendala yang dihadapi pelaku industri kecil pangan Desa Gunung Manik adalah perkembangan usaha yang stagnan akibat terbatasnya lokasi dan jaringan pemasaran produk. Solusi yang ditawarkan dari masalah tersebut adalah mempergunakan media sosial sebagai sarana untuk memperluas pemasaran produk dengan memanfaatkan website usaha desa media sosial dan toko jual beli online (e-commerce) seperti toko pedia, shopee, buka lapak, lazada dan sesbagainya.

Pelatihan sistem pemasaran on line dimulai dari pemanfaatan mediasosial melalui whataps, facebook, twitter, instagram dan website desa. Berpromosi digital melalui media sosial cukup mudah. Namun, media sosial masih belum bisa mengakomodir pembayaran dan menelusuri jejak sang pembeli. Tahap berikutnya pelaku Usaha mikro kecil (UMK) perlu menguasai digital commerce, dengan memiliki sebuah website atau situs yang cukup komprehensif atau memasuki ranah e-commerce. Salah satunya adalah mencoba "membuka toko" di marketplace online, seperti bukalapak, tokopedia, shoppe, dan 
sebagainya. Melalui kecanggihan dunia digital saat ini, pemilik UMKM tidak hanya mempromosikan produknya, tetapi juga dapat mengetahui target pasar, cara penjualannya, termasuk mengontrol sistem pembayarannya (KR, Mohamad Asyad, Himawan dan Gibza Adam F, 2015).

Penyuluhan pemasaran online berlangsung di gedung serbaguna desa Gunung Manik yang dihadiri oleh anggota karang taruna dan aparat Desa Gunung Manik. Pemanfaatan media internet untuk promosi produk lokal melalui media web desa sejalan dengan pengembangan desa Gunung Manik sebagai desa digital yang sedang dirintis oleh Pemda Kabupaten Sumedang.

\section{Faktor Pendorong dan Penghambat Kegiatan PPM Kewirausahaan}

Berdasarkan hasil evaluasi diketahui terdapat beberapa faktor pendukung dan penghambat atas pelaksanaan PPM ini. Letak geografis, potensi SDA, SD teknologi dan aparat pemeritah desa Gunung Manik sangat mendukung pelaksnaan PPM-KKN kewiausahaan berjalan dengan baik. Potensi kelembagaan yang dapat mendukung aktifitas PPM kewirausahaan berupa keberadaan koperasi simpan pinjam Guna Raharja yang sedang dirintis dan beroperasi sekitar dua tahun serta terbentuknya BUMDES Gunung Manik. Kedua kelembagaan ekonomi desa tersebut sedang dalam proses pembenahan organisasi dan pengurusan badan hukum. Selain iu desa Gunung Manik berlangsung program rintisasn desa digital.

Terdapat kendala sumberdaya manusia dalam pelaksanaan PPM ini diantaranya padatnya aktifitas warga masyarakat dalam kehidupan kesehariannya, sehingga warga Desa Gunung Manik tidak memiliki waktu luang yang banyak untuk mengikuti pertemuan atau rapat. Lingkungan Sosial masyarakat desa Gunung Manik sebagai desa perkotaan Swadaya dengan aksesibilitas yang tinggi ke pusat pertumbuhan kecamatan dan kabupaten mempengaruhi tingkat kekompakan warga desa dalam berinteraksi sosial. Banyak warga desa Gunung Manik yang bekerja di luar desa. Kesulitan mengumpulkan warga untuk berpartisipasi dalam kegiatan di desa dikemukakan oleh salah seorang aparat desa, sehingga kegiatan rapat atau pertemuan desa jarang dihadiri oleh warga dalam jumlah yang banyak.

\section{SIMPULAN}

Program PPM-KKN kewirausahaan yang dilaksanakan di Desa Gunung Manik melalui penyuluhann inovasi produk dan pemasaran online (e-commerce) terlaksana dengan baik sesuai dengan tujuan program. Diharapkan terjadi peningkatan pengetahuan, sikap dan keterampilan peserta penyuluhan dalam hal kreativitas usaha,inovasi produk dan pemanfaatan teknologi internet. Faktor pendorong terlaksananya PPM berupa motivasi peserta yang kuat untuk memperbaiki cara berusaha dan memasarkan produknya, kemudahan dalam koordinasi dengan aparat desa dan potensi sumberdaya pertanian, peternakan dan usaha industri kecil, aksesibilitas desa Gunung Manik sangat baik ke pusat kecamatan, pasar dan sarana pelayanan, kelembagaan BUMDES, koperasi simpan pinjam serta adanya program yang sejalan dengan kegiatan PPM berupa perintisan pengembangan desa digital. Sedangkan Faktor penghambat dalam kegiatan PPM ini adalah kondisi pemukiman yang saling berjauhan, sebagian besar warga memiliki curahan waktu kerja yang tinggi menyebabkan sulitnya waga menghadiri pertemuan yang dilakukan oleh tim KKN. Pelaksanaan penyuluhan kewirausahaan dan pembuatan website desa terkendala oleh keterbatasan keterampilan pemangaatan teknologi komunikasi. Berdasarkan hasil diskusi, evaluasi dan penggalian informasi selama berlangsungnya program,diketahui bagwa pelatihan dan pendampingan lebih lanjut diperlukan khususnya di bidang pengelolaan website desa. Melalui pelatihan dan pendampingan diharapkan pelaku UMK dapat memperoleh ijin PIRT dan memasarkan produknya ke segment pasar yang lebih luas guna meningkatkan kesejahteraan masyarakat Desa Gunung Manik.

\section{UCAPAN TERIMAKASIH}

Ucapan terimakasih disampaikan kepada Direktur Riset, Pengabdian pada Masyarakat dan Inovasi Unpad, Tim PPM-KKN kewirausahaan, dan warga masyarakat desa Gunung Manik yang telah Mendukung terlaksananya kegitan PPM-KKN Kewirausahan.

\section{DAFTAR PUSTAKA}

Anonim, (2018). Profil Desa Gunung Manik Tanjungsari Sumedang. Pemerintah Daerah Sumedang

Basrowi, B. (2011). Kewirausahaan Untuk Perguruan Tinggi. Bogor: Ghalia Indonesia.

Cahyani, F. R. (2015). Hubungan Motivasi Berwirausaha dengan Kesiapan Berwirausaha Siswa Kelas IX Program Keahlian Jasa Boga di smk Negeri 6. Skripsi Universitas Negeri Yogyakarta

Endra Yuafanedi Arifianto (2018). Optimalisasi Potensi Industri Pangan Dengan Pengolahan Limbah Industri dan Pemasaran Digital . 
Proseding Entrepreneur Annual Conference on Community Engagement 26 - 28 Oktober 2018 Hotel Swiss-Bellin Airport Surabaya

Hadiyati 2011. Kreativitas dan Inovasi Berpengaruh Terhadap kewirausahaan Usaha kecil. Jurnal Manajemen dan Kewirausahaan, VOL.13, NO. 1, p. 8-16. ISSN 14570243

Hepi Hapsari, Endah djuwendah dan Lies S, (2015). Optimalisasi Manajemen Usaha Keripik SIngkong Skala Industri Rumah Tangga( Kasus dpada UMK Hasil tani Gunung Geulis dan Kesha Snack Kecamatan Jatinangor, Kabupaten Sumedang. Prosiding Seminar Nasional 4th UNS SME's Summit \& Award 2015 “ Sinergitas Pengembangan UMKM dalam Era Masyarakat Ekonomi ASEAN (MEA)" ISBN: 978-602-397-012-4 UNS. https://psp-kumkm.lppm.uns.ac.id/wp-content/ uploads/sites/21/2016/01/hepi-hapsariprosiding-sme-s-combinedpdf_1.pdf

Husaeni, U. A. (2017). Potensi Ekonomi Desa Menuju Desa Mandiri (Studi di Desa Sukamanah Kecamatan Karangtengah Kabupaten Cianjur). Journal of Empowerment, 1(1), 1-11.

KR, Mohamad Asyad, Himawan dan Gibza Adam F. (2015). Pengembangan Kewirausahaan UMKM Suatu Tantangan di Era Digital $J p$ Feb UNSOED . Vol 5(1) http://www.jp.feb. unsoed.ac.id/index.php/sca-1/article/view/623

Purba, D. F., Nuraida, L., \& Koswara, S. (2014). Efektivitas program peningkatan mutu dan keamanan pangan industri rumah tangga pangan (IRTP) di Kabupaten Cianjur. Jurnal Standardisasi, 16(2), 103-112.

Selfiawaty Fausiah. 2016. Efektivitas Pembinaan Usaha Industri Kecil Olahan Pangan Oleh Dinas Koperasi UMKM Perindustrian Dan Perdagangan Kabupaten Sigi (Studi Di Kecamatan Sigi Biromaru. Jurnal Katalogis, Volume 4Nomor 1, Januari 2016 p. 68-81. ISSN: 2302-2019

Sembiring, S. (2009). Penyuluhan Kewirausahaan Kepada Generasi Muda Dan Pengusaha dalam Rangka Meningkatkan Kesejahteraan Masyarakat Di Kecamatan Kiaracondong Kota Bandung. abmas, 81 .

Sulistiyani. 2010. Pengaruh Manajerial Kreativitas Program Pemasaran dan Kemampuan berinovasi terhadap kinerja usaha kecil dan menengah di Kota Semarang. Economica jurnal ekonomi Islam. Fakultas Ekonomi dan Bisnis Islam UIN Walisongo. Vol 1 no 1,p. 89100

Sutisna, S., \& Djuwendah, E. (2019). Peningkatan Kemampuan Manajerial Usaha Mikro Kecil di Desa Sukadana Kecamaan Cimanggung Kabupaten Sumedang. Dharmakarya, 8(4), 220-224.

Syafariani, R. F., \& Sitanggang, A. S. (2017). Penyuluhan Pemasaran Dan Pelatihan Inovasi Panganan Hortikultura Desa Nagrog Cicalengka (Jawa Barat). Journal Of Empowerment, 1(2), 121-138. 